\title{
Gender-Responsiveness and Its Influence on Gender Equality and Economic Performance of State Colleges and Universities
}

\author{
Ma. Teresa B. Ballados \\ Carlos Hilado Memorial State College, Bacolod City \\ ballados2017@gmail.com \\ https://orcid.org/0000-0001-8110-4378 \\ Joseph G. Guevarra \\ University of Negros Occidental- Recoletos, Philippines \\ jguevarra6@gmail.com
}

\begin{abstract}
State Colleges and Universities (SUCS) are expected to take initiatives to promote gender and development. This study aims to assess gender-responsiveness and its influence on gender equality and the economic performance of SUCs in Negros Occidental, Philippines. The descriptive research design was employed and utilized a researcher-made questionnaire to gather data from randomly selected 36 administrators and 236 employees of SUCs. Using the mean, descriptive results showed high gender responsiveness and a great extent of influence on gender equality and the economic performance of SUCs. Also, the results of the Analysis of Variance and Kruskal-Wallis revealed that significant differences occurred in the level of gender responsiveness and the extent of influence on gender equality among SUCS. Employing Spearman rho, significant relationships were found among gender responsiveness, influence on gender equality, and economic performance. Higher genderresponsiveness may lead to a greater influence on the promotion of gender equality and economic performance.
\end{abstract}

Keywords: Business Management, Gender-Responsiveness, Gender Equality, Economic Performance, Descriptive, State Colleges and Universities, Negros Occidental, Philippines

Date Submitted: May 20, 2020

Date Revised: June 11, 2020

Date Accepted: June 15, 2020

\subsection{Introduction}

In organizations, gender issues were a complex phenomenon found in organizational structures, processes, and practices (Stamarski and Son Hing (2015). 
In the academic world, although women are more represented than they used to be, they are still discriminated against in academic positions and activities (Goastellec \& Pekari, 2013). More opportunities have been given to males, especially for managerial positions, decision-making power, and social networking (Shauka, Siddiquah, \& Pell, 2014). Profeta (2017), Flynn, Cavanagh, and Bilimoria (2015), Organization for Economic Co-Operation and Development [OECD] (2017), and Currie and Hill (2013) claim supports the research results that women around the world are less represented in decision-making and managerial positions.

In the Philippines, the Women Development and Nation Building Act (RA 7192) provides that government departments shall guarantee that women benefit equitably and engage directly in the development programs and projects of departments to ensure the full participation and involvement of women in the development process. Likewise, Magna Carta of Women (RA 9710) emphasizes the promotion of women empowerment, pursues equal opportunities for women and men, and ensures equal access to resources, development results, and outcome. Furthermore, CHED released Memorandum Order No. 01 (2015), which states the guidelines seeking to introduce and institutionalize gender equality and gender-responsiveness and sensitivity in the various aspects of Philippine higher education (Lualhati, 2019).

Researches related to gender and development in higher education are only limited to: profiling and status of women (Frances, 2017; Frances, 2018), opportunities and employability challenges of women (Zhong \& Gou, 2017), women leadership and organizational culture (Mabokela \& Mlambo, 2017; Zhao \& Jones, 2017; Morley, Berma, \& Hamid, 2017), women issues of economic crisis (Papadimitriou, 2017), the vulnerability of gender equality to neoliberalism (Aavik, 2017), awareness and status of implementation of gender and development (Albaladejo, 2016; Sumadsad \& Tuazon, 2016), women's place in academia (Goastellec \& Vaira, 2017), gender equality (Robertson, Williams, Jones, Isbel, Loads \& Maxwell, 2018; David, 2017; Henkel, 2017; Grenz et al., 2008), gender inequality, disparity, and issues (Machin \& Wyness, 2017; Peterson, 2011); gender mainstreaming implementation (Delavin, 2017), and gender sensitizing (Lualhati, 2019).

However, according to Shreve (2016), there are a limited number of studies on gender-responsiveness. There were minimal empirical studies investigating management's responsiveness to gender issues and how it affects the promotion of gender equality and economic performance of higher educational institutions, particularly the state colleges and universities. For this reason, the current study exclusively dealt with the assessment of gender-responsiveness and its influence on promoting gender equality and economic performance. Based on the proposition mentioned, the objective of the study was to determine the level of gender-responsiveness of SUCS and its influence on promoting gender equality and economic performance.

\subsection{Framework of the Study}

The paper theorized that high management's responsiveness to gender issues would promote gender equality and positive economic performance. The Feminist Economic (FE) Theory was used to support this study. Feminist economists 
believe that uncovering the gender bias in economics is a necessary prelude to constructing economics that encompasses the perspectives and embodies the realities of both women and men (Kuiper \&Sap 1995). From this point of view, the structures of acknowledgment, redistribution, and representation of men and women are considered important components of the global functioning of the economy (Fraser, 2013). However, the Asian Development Bank (2013) identified gender gaps such as human capital and decent work that hinder women's participation in economic activities. On the other hand, the Asian Development Bank (2017) cited dimensions of gender equality: human development, economic empowerment, voice and decisionmaking, and reduced vulnerability to risks and shock.

A gender-responsive organization adopts a systematic approach (Leal \& Saguibo, 2018) and ensures that gender needs, realities, and issues are consistently and specifically considered in policies, programs, and projects (Tirivanhu \& van Rensburg (2017). In line with this, it may result in equal opportunities for men and women, whereby attained an increasing proportion of minority and women in senior goals in the organization (Greene \& Kirton, 2002). Likewise, equality may have the potential to improve productivity, opportunity, and competitiveness (Moore, 1999). Moreover, gender-responsiveness might also affect the organization's economic performance in terms of income (Marr, 2012), reduction of cost, employment generation, and encouraged investment (Parida, 2007).

Applied in the workplace, Feminist Economic Theory, women, are included as an important part of the organization structure. Gender inclusion is considered in the development of human capital and the improvement of decent work. The management practices may be aligned in providing opportunities for both men and women employees to attain professional development, economic development, and welfare and development.

\subsection{Methods}

The study employed a descriptive research design. According to Flores (2016), descriptive research uses a set of scientific methods and procedures to collect raw data and create data structures that describe existing characteristics of a defined target population. In this study, the data regarding gender-responsiveness in terms of human capital and decent work, the influence of gender-responsiveness on the promotion of gender equality as to human development, economic empowerment, voice and decision-making, and reduced vulnerability to risk and shock as well as the influence of gender-responsiveness on the economic performance of SUCs like improvement in income, reduction in cost, employment generation, and encouraged investment were gathered, analyzed, and interpreted. Hence, descriptive design was most appropriate.

Stratified-random sampling was employed to identify the respondents, comprising 36 school administrators and 236 employees of the three (3) public HEls in Negros Occidental who are assigned at their main campus. This study utilized a researcher-made questionnaire that was structured based on the Women's Empowerment Principles (UN Women, 2011) and strategies to promote workers' wellbeing and business performance (O'Connor \& Manaus, 2017). The questionnaire is composed of five (5) parts. Part I includes the name and the profile of the respondents; 
Part II consists of items that measure the gender-responsiveness. Part III comprises items that assess the influence of gender-responsiveness on the promotion of gender equality. Part IV consists of items that assess the influence of gender-responsiveness on economic performance. Part $V$ explores the challenges encountered by the school management relative to the promotion of gender and development.

The researcher-made survey questionnaire was subjected to content validity by ten experts in human resource management and gender and development using the Content Validity Ratio (CVR) of Lawshe (1975). The validated questionnaire included 116 out of 120 items, and four (4) items were discarded, and the CVR result was 0.836 interpreted as valid. A reliability testing was conducted to 30 administrator-respondents and 30 employee-respondents. Using Cronbach's alpha, the reliability test results showed 0.989 for gender-responsiveness and its effect on the promotion of gender equality and 0.910 for effect on economic performance. Both are interpreted as highly reliable. In the conduct of the survey, consent from the participants, and the utmost confidentiality of the data were observed.

The data for the descriptive objectives were analyzed using descriptive statistics such as mean and standard deviation. In contrast, for inferential statistics, KolmogorovSmirnov was applied to determine the normality of the data. An analysis of Variance was used to measure the significant difference in the level of gender-responsiveness when grouped by SUC because the data was normally distributed. In contrast, the data for a significant difference in the influence on the promotion of gender equality and economic performance were not normally distributed; thus, Kruskal-Wallis was applied. Likewise, the data to measure the significant relationship between gender- responsiveness, and influence on the promotion of gender equality and between gender responsiveness and influence on economic performance were also not normally distributed; hence, Spearman rho was used.

\subsection{Results and Discussion}

\section{Level of Gender-Responsiveness}

The data in Table 1 show the level of gender-responsiveness of the three (3) SUCs in terms of human capital $(M=3.92 ; S D=0.86)$ and decent work $(M=3.791$; $S D=0.93)$ and the overall result $(M=3.86 ; S D=0.90)$ were found high which means that all GAD programs to address gender issues, as covered in this study are implemented in most instances. According to the Asian Development Bank (2013), although the organization is highly responsive to the development of human capital, women's labor force participation rate is much lower than men. In contrast, higher levels of productivity and incomes will be more able to provide decent work.

In higher educational institutions, particularly SUCS, they more likely committed to ensuring that gender issues related to human capital and decent work are accordingly and properly resolved. The high gender responsiveness of the SUCS may be affected by the gender-responsive budgeting of the government. The national government is providing the SUCs of at least a five percent budget based on their Annual Appropriation, which should be used in the implementation of the GAD programs. 
Additionally, responding to human capital and decent work-related gender issues can be resolved through appropriate budgeting. These findings support the claim of Nair and Moolakkattu (2018) that implementation of gender-responsive programs and activities requires gender-responsive budgeting (GRB), and a common tool used by organizations with great concern on gender and development (OECD, 2017). In addition, UNESCO (2012) ascertained that organizations require to have a culture of gender inclusion (cited in Zuabi, 2015) and supportive structures and affirmative action from university leaders (Grenz et al., 2009).

However, it can be noted that human capital issues were given greater emphasis by SUCS than the decent work, as reflected in the mean scores. This means that SUCs implement GAD programs in most instances. It appears that SUCs strive to ensure that both men and women employees are given an equal chance to access professional development rights and privileges. The findings affirm the study of O'Connor and Manaus (2017) that investment in professional development can lead to strengthening the workforce and development of women can have remarkable benefits to the organization (Wodon \& De la Briere, 2018). Thus, SUCs have a high probability of adherence to the Principles of Women Empowerment (UN Women, 2011).

Nevertheless, there is an increasing number of feminist studies showing patriarchal patterns in management and leadership in higher education (David, 2017) and very few women in leadership and governance (International Monetary Fund, 2014 ) and this is a widespread issue in numerous higher education systems worldwide (Papadimitriou, 2017).

Gender-responsiveness to decent work issues obtained a lower mean score than human capital, which appears to be affected by the lack of access to child and independent care, and limited health insurance services. Kasan, Cabanos, Escosura, Lemus, and Mantes (2016) argue that organizations need to develop proactive measures to protect their employees and the company. Drago and Hyatt (2003) and Kato and Kodama (2016) suggested company child care assistance, including onsite daycare centers and a reimbursement program that can alleviate women employees' work and family responsibilities.

Table 1. Level of Management's Gender-Responsiveness

\begin{tabular}{lcll}
\hline Management's Gender-Responsiveness & M & SD & Interpretation \\
\hline Human capital & 3.92 & 0.86 & High Responsiveness \\
Decent Work & 3.79 & 0.93 & High Responsiveness \\
As a whole & 3.86 & 0.9 & High Responsiveness \\
\hline
\end{tabular}

\section{Extent of Influence of Gender-Responsiveness on the Promotion of Gender Equality}

In Table 2, the data show that the overall extent of influence of genderresponsiveness on the promotion of gender equality in SUCs in Negros Occidental was a great extent $(M=3.90 ; S D=0.90)$. Specifically, a great extent of influence was found in human development $(M=3.90 ; S D=0.90)$, economic empowerment $(M=3.88 ; S D=0.92)$, reduced vulnerability to risk, and shock ( $\mathrm{M}=3.90 ; \mathrm{SD}=0.91)$, and voice and decisionmaking $(M=3.84 ; S D=0.93)$. The results indicated that gender equality is experienced 
in the majority of the instances by both men and women employees of SUCs. Asian Development Bank (2017) cited that human development, economic empowerment, reduced vulnerability to risk and shock, and voice and decision-making are important indicators of gender equality.

In consonance with the results of the study, the effect of the implementation of the GAD program is better on the human development of both men and women employees of SUCS in terms of education and training. The findings connote the effectiveness of SUCS management to address human capital issues. It substantiates the research studies of Profeta (2017) and Lahti (2013) that the soundness of the gender response actions may give both men and women equal opportunities to be involved in a competitive process.

In terms of the effect of gender responsiveness on the promotion of economic empowerment, the better effect was ascertained. Santiago (2008) discloses that the promotion of women's economic empowerment is one of the key priorities of the Philippine Government's Framework Plan for Women. However, the findings contradict the study of Frances (2018) that women have not been equally successful in the economic domain, and McElhaney and Smith's (2017) that the wage gap contributes towards continuing gender inequality.

The least extent of influence of gender-responsiveness was noted in the promotion of voice and decision-making. The findings of this study support previous studies that women in most prestigious higher education sectors tend to have limited representation in the decision-making process, and academic leadership positions (Goastellec \& Pekari, 2013; Lahti, 2013; Bagilhole \& White, 2011; Cobanoglu, 2018). These are influenced by societal, organizational, and individual factors (Lahti, 2013). Furthermore, in the study of Goastellec and Pekari (2013), they concluded that in the higher education system, women perceived that they are less influential men.

Table 2. Extent of Influence Gender-Responsiveness on the Promotion of Gender Equality

\begin{tabular}{llll}
\hline Areas of Promotion of Gender Equality & $\mathrm{M}$ & $\mathrm{SD}$ & Interpretation \\
\hline Human Development & 3.9 & 0.90 & Great Extent \\
Economic Empowerment & 3.88 & 0.92 & Great Extent \\
Voice and Decision-making & 3.84 & 0.93 & Great Extent \\
Vulnerability to Risk and Shock & 3.9 & 0.91 & Great Extent \\
As a whole & 3.88 & 0.92 & Great Extent \\
\hline
\end{tabular}

\section{Extent of Influence of Gender-Responsiveness on the Economic Performance}

Table 3 presents that the overall influence of gender-responsiveness on the perceived economic performance of the three (3) SUCs in Negros Occidental was a great extent $(M=3.98 ; S D=0.85)$. Particularly, greater extent of influence were registered in improvement in income $(M=4.07 ; S D=0.73)$, employment generation $(M=43.93 ; S D=0.81)$, reduction in cost $(M=3.93 ; S D=0.73)$, and encouraged investment $(M=3.92 ; S D=0.92)$. The findings of the study suggest that the influence of gender- 
responsiveness on the economic performance in SUCS is positive, and the results are shown in the majority of instances. The gender-responsiveness of the organization may influence its economic performance in terms of income (Marr, 2012), reduction of cost, employment generation, and encouraged investment (Parida, 2007).

The extent of influence of gender responsiveness on the economic performance profile of SUCs is more likely due to a high level of gender responsiveness. According to Hunt, Layton, and Prince (2015), organizations with a strong track record and emphasis on gender issues are $15 \%$ more likely to have higher earnings than their peers.

The findings show that the influence of gender-responsiveness on improvement in income in SUCS is perceived as more likely satisfactory. The previous research studies revealed that incorporating gender inclusion in the organization can bring positive impacts on income, higher productivity, overall quality improvement, benefits outweigh the cost, maximize organizational competitive advantage, and increase the well-being of the organization (Zuabi, 2015; O'Connor and Manaus, 2017, IMF 2016; Sharma \& Sharma, 2014; Profeta, 2017; Sels et al., 2006 cited in Hanaysha, 2016; Shreve, 2016; Hill, Jones, and Schilling, 2014) which affirmed by the findings of the study.

However, the influence was least found in encouraged investment. Hernandez, Vera, and Ugedo (2016) claimed that lower debt financing of the organizations is due to the limited presence of women managers in the organization. Moreover, Remme, Siapka, Vassall, Heise, Jacobi, Ahumada, and Watts (2014) indicate that improvement in addressing women's well-being is an appropriate approach to support more genderequitable investment decisions.

Table 3. Extent of Influence of Gender-Responsiveness on the Economic Performance

\begin{tabular}{llll}
\hline Areas of Economic Performance & $\mathrm{M}$ & $\mathrm{SD}$ & Interpretation \\
\hline Improvement in Income & 4.07 & 0.73 & Great Extent \\
Reduction in Cost & 3.93 & 0.81 & Great Extent \\
Employment Generation & 4.00 & 0.92 & Great Extent \\
Encouraged Investment & 3.92 & 0.92 & Great Extent \\
As a whole & 3.98 & 0.85 & Great Extent \\
\hline
\end{tabular}

\section{Difference in the Level of Management's Responsiveness to Gender Issues}

Table 4 shows the Analysis of Variance, and the results indicate that when grouped according to SUC, significant differences in the level of gender-responsiveness occurred in human capital $[F(2,275)=3.05, p=0.049]$, and decent work $[F(2,275)=3.05$, $p=0.049]$, hence null hypotheses are rejected. The significant differences may be due to the variation in the organizational culture, structure, management's gender priorities and types of programs, projects, and activities implemented by each SUC.

Along with these results, each institution's level of gender-responsiveness depends on the environment and administrative leadership priorities of each SUC. It can be pointed out also that the significant variation in the gender-responsiveness of SUCS probably caused by the dissimilarity in the existing GAD policies and programs that affects the budget allocation in GAD programs. The findings of the study confirm the claims of Stamarski and Son Hing (2015) and UNESCO (2012, cited in Zuabi, 2015) 
that gender concerns in organizations are complex phenomena found in organizational structures, processes, and practices and governance. Silva (2002) suggested that in a gender-responsive setup, leaders should view personnel as partners. The Philippine Commission on Women (PCW), United Nations Development Fund for Women (UNIFEM), and Convention of the Elimination of All Forms of Discrimination against Women (CEDAW) have reiterated that gender work is obligatory to all offices and administrators should have to make an effort to provide equal opportunities for everyone (Lualhati, 2019).

Table 4. Difference in the Level of Gender-Responsiveness by SUC

\begin{tabular}{ccccc}
\hline Gender-Responsiveness & M & SD & F & p-value \\
\hline A. Human Capital & & & & \\
SUC 1 & 3.84 & 0.86 & $3.05^{*}$ & \\
SUC 2 & 3.91 & 0.80 & $(2,275)$ & .049 \\
SUC 3 & 4.1 & 0.84 & & \\
B. Decent Work & & & & \\
SUC 1 & 3.63 & 0.94 & $3.286^{*}$ & \\
SUC 2 & 3.74 & 0.93 & $(2,275)$ & .000 \\
SUC 3 & 4.11 & 0.84 & & \\
\hline
\end{tabular}

Note: "The difference is significant when $p \leq 0.05$

\section{Difference in the Extent of Influence of Gender- Responsiveness to the Promotion of Gender Equality}

Table 5 shows the Kruskal-Wallis results that significant differences in the extent of influence of gender-responsiveness on equality promotion were found in human development $[\chi 2(2)=7.89, p=0.019]$, economic empowerment $[\chi 2(2)=10.37$, $\mathrm{p}=0.006]$, voice and decision-making [ $\chi 2(2)=7.16, p=0.028]$, and reduced vulnerability to risk and shock [ $\chi 2(2)=8.94, p=0.011]$ occurred among SUCs. Hence, null hypotheses are rejected. The significant variations could be due to the significant difference in gender-responsiveness in resolving gender issues in human capital and decent work.

It is noteworthy to state that the extent of influence of gender-responsiveness on gender equality is much dependent on the level of gender-responsiveness. These findings support Monks (2007) that the implementation of GAD policies can promote responsive action and gender equality. Wodon and De La Briere (2018) concluded that women's investment is the right thing to do in promoting gender equality, which may lead to an improvement in economic conditions. The study results affirm the Feminist Economic (FE) Theory that both men and women have equal economic opportunities without gender bias (Kuiper \& Sap, 199). Women should be given the entrepreneurial opportunities and be a manager and leader (Pérez Orozco, 2014) and be more effective (Williams, 2010), creative and innovative (Marinova, Plantegna, \& Remery, 2010). However, gender equality in HEls remained uneven across Europe and other nations of the global north (David, 2017). 
Table 5. Difference in the Extent of Influence of Gender-Responsiveness to the Promotion of Gender Equality by SUC

\begin{tabular}{ccccc}
\hline Influence on Gender Equality & $\mathbf{M}$ & SD & $\mathbf{X}^{\mathbf{2}}$ & $\mathbf{p}$-value \\
\hline Human Development & & & & \\
SUC 1 & 3.79 & 0.91 & $7.89^{*}$ & \\
SUC 2 & 3.88 & 0.82 & $(2)$ & 0.019 \\
SUC 3 & 4.1 & 0.9 & & \\
\hline
\end{tabular}

Economic Empowerment

$\begin{array}{lllcl}\text { SUC 1 } & 3.75 & 0.95 & 10.37^{*} & \\ \text { SUC 2 } & 3.87 & 0.83 & (2) & 0.006 \\ \text { SUC 3 } & 4.01 & 0.94 & & \end{array}$

Voice and Decision-making

\begin{tabular}{ccccc} 
SUC 1 & 3.73 & 0.95 & $7.16^{*}$ & \\
SUC 2 & 3.87 & 0.83 & $(2)$ & 0.028 \\
SUC 3 & 4.01 & 0.94 & & \\
\hline $\begin{array}{c}\text { Reduced Vulnerability to Risk \& } \\
\text { Shock }\end{array}$ & & & & \\
SUC 1 & 3.77 & $0.94^{*}$ & \\
SUC 2 & 3.92 & 0.84 & $(2)$ & 0.011 \\
\hline
\end{tabular}

Note: "The difference is significant when $p \leq 0.05$

Difference in the Extent of Influence of Gender-Responsiveness on Economic Performance

Table 6 shows the Kruskal-Wallis results that, no significant differences in the extent of influence of gender-responsiveness on the economic performance of three (3) SUCs were found in improvement in income $[\chi 2(2)=4.20, p=0.811]$, reduction in cost $[\chi 2(2)=2.16, p=0.339]$, employment generation $[\chi 2(2)=0.417, p=0.812]$, and encouraged investment $[\chi 2(2)=0.996, p=0.608]$ existed among SUCs. Therefore null hypotheses are accepted. The results imply that the effects of gender responsiveness on the economic performance among the three (3) SUCs as to the improvement of income, reduction in cost, employment generation, and encouraged investment are equally the same.

Administrators in three (3) SUCs more likely believed that gender responsiveness could lead to an improvement in academic organization's economic performance. If women employees are provided with the opportunity to participate equally with men employees in performing the different functions of the institutions, it might lead to greater improvement in income, reduction in cost, employment generation, and encouraged investment. The findings of the study support the argument of Noland, Moran, and Kotschwar (2016) that the addition of more than one percentage point to the organization's net margin when 30 percent of leaders are women compared to otherwise similar firms with no female leaders. Also, Profeta (2017) claims that the participation of women in decision-making influences better economic performance. 
Table 6. Difference in the Extent of Influence of Gender-Responsiveness on Economic Performance by SUC

\begin{tabular}{lllll}
\hline Influence on Economic Performance & $M$ & SD & $x^{2}$ & $p$-value \\
\hline
\end{tabular}

Improvement in Income

\begin{tabular}{lllll} 
SUC 1 & 4.06 & 0.79 & 4.2 & \\
SUC 2 & 3.96 & 0.071 & $(2)$ & 0.811 \\
SUC 3 & 4.27 & 0.52 & & \\
\hline
\end{tabular}

Reduction in Cost

\begin{tabular}{lcccc} 
SUC 1 & 3.84 & 0.84 & 2.16 & \\
SUC 2 & 3.82 & 0.84 & $(2)$ & 0.339 \\
SUC 3 & 4.32 & 0.49 & & \\
\hline
\end{tabular}

Employment Generation

\begin{tabular}{lcccc} 
SUC 1 & 3.95 & 1.01 & & \\
SUC 2 & 3.94 & 0.92 & 0.417 & \\
SUC 3 & 4.25 & 0.51 & $(2)$ & 0.812 \\
\hline
\end{tabular}

Encourage Investment

\begin{tabular}{lllcl} 
SUC 1 & 3.86 & 1.03 & 0.996 & \\
SUC 2 & 3.8 & 0.77 & $(2)$ & 0.608 \\
SUC 3 & 4.3 & 0.52 & & \\
\hline
\end{tabular}

Note: "The difference is significant when $p \leq 0.05$

\section{Relationship between Gender Responsiveness and its Influence on Gender Equality and Economic Performance}

Table 7 shows the results of the Spearman rank correlation. The results of the study indicated that significant relationships occurred between gender-responsiveness and its influence on the promotion of gender equality $[\rho(276)=0.869, p=0.000]$, and on economic performance $[\rho(276)=0.664, p=0.000]$; therefore, null hypotheses are rejected.

The results further revealed that gender-responsiveness has strong positive relationships with the influence on the promotion of gender equality and economic performance. Gender-responsive SUCs which give investment priority to the development of both men and women can lead to the promotion of gender equality in terms of human development, economic empowerment, voice and decision-making, and reduced vulnerability to risk and shock. Likewise, it can steer improvement in the institution's economic performance in terms of improvement in income, reduction in cost, employment generation, and encouraged investment.

The results support the theory developed in this study that high genderresponsiveness to gender issues will promote gender equality and positive economic performance, which is also grounded from the Feminist Economic Theory. 
The findings of the study corroborate with the claim of Profeta (2017) that gender inclusion in the institutions and organizations can lead to the promotion of gender equality. Also, Kabeer (2012) spells out evidence that shows that there is a reasonably strong empirical underpinning for the claim that gender equality has a positive influence on economic performance.

Further, the study can be considered as evidence that SUCs are gearing towards achieving the Sustainable Development Goals (SDGs) that focus on the promotion of gender equality (OECD, 2017) and promotes women's economic participation (International Monetary Fund, 2014).

Table 7. Relationship between Gender-Responsiveness and Gender Equality and Economic Performance

\begin{tabular}{lccc}
\hline Variables & Coefficient Correlation & df & p-value \\
\hline $\begin{array}{l}\text { Gender-Responsiveness and } \\
\text { Gender Equality }\end{array}$ & $0.869^{*}$ & 276 & 0.000 \\
$\begin{array}{l}\text { Gender-Responsiveness and } \\
\text { Economic Performance }\end{array}$ & $0.664^{*}$ & 276 & 0.000 \\
\hline
\end{tabular}

Note: "The difference is significant when $\mathrm{p} \leq 0.05$

\subsection{Conclusion}

The achievement of gender equality and improvement in the economic performance of academic institutions like SUCS is more likely dependent on the priority programs, projects, and activities set by the management. It entails effective formulation and proper implementation of Gender and Development Programs, which will set the management priorities. GAD programs may contain specific strategies that might address issues related to human capital and decent work.

Since the findings showed that high level of gender-responsiveness to gender issues in terms of human capital and decent work resulted to a great extent of influence on the promotion of gender equality in terms of human development, economic empowerment, voice and decision-making and reduced vulnerability to risk and shock and also the great extent of influence on economic performance as to the improvement in income, reduction in cost, employment generation and encouraged investment, the management of SUCs in Negros Occidental may explore the possibility to design and implement GAD programs that may equally promote and improve the capabilities, status, and welfare of both men and women employees that may ultimately lead in the development of the SUCs.

\section{REFERENCES}

Aavik, K. (2017). Doing neoliberalism on campus: The vulnerability of gender equality mechanisms in Estonian academia. Gender a Vyzkum / Gender and Research, 18(1), 130-153. https://doi.org/10. 13060/25706578.2017.18.1.353

Albaladejo, E. M. (2016). Implementation of Gender and Development among Higher Education Institutions: Input to GAD Enhancement Program. JPAIR Institutional Research, 7(1). https://doi.org/10.7719/ irj.v7i1.368 
Aguilar-Delavin Emilio Espinosa Sr, E. B. (2017). Gender and Development Implementation in Masbate State College, Philippines. Asia Pacific Journal of Multidisciplinary Research, 5(3), 130-136.

Asian Development Bank (2013). Gender Equality in the labor market in the Philippines. Retrieved from https://www.adb.org/sites/default/files/publication/31194/ gender-equality-labor-market-philippines.pdf

Asian Development Bank (2017). Thematic Evaluation: Asian Development Bank Support for Gender and Development (2005-2015). Retrieved from https://www.adb.org/sites/default/files/evaluation-document/181135/files /tes-gender- anddevelopment.pdf

Bagilhole, B., \& White, K. (2011). Gender, power, and management: A cross-cultural analysis of higher education. Gender, Power, and Management: A Cross-Cultural Analysis of Higher Education (pp. 1-215). Palgrave Macmillan. https://doi.org/10.1057/9780230305953

Christiansen, L., Lin, H., Pereira, J., Topalova, P., Ariss, R. T., \& Koeva, P. (2016). Unlocking female employment potential in Europe: drivers and benefits. Washington, DC: InterDC:onal Monetary Fund.

Çobanoğlu, F. (2018). Gender equality in Turkish higher education. International Journal of Higher Education, 7(5), 97-113. https://doi.org/10.5430/ijhe.v7n5p97

Currie, J., \& Hill, B. (2013). Gendered universities and the wage gap: A case study of a pay equity audit in an Australian University. Higher Education Policy, 26(1), 65-82. https://doi.org/10.1057/ hep.2012.19

David, M. E. (2015). Women and Gender Equality in Higher Education? Education Sciences, 5(1), 10-25. doi: 10.3390/educsci5010010

Drago, R., \& Hyatt, D. (2003). Symposium: The Effect of Work-Family Policies on Employees and Employers. Industrial Relations, 42(2), 139-144. Retrieved from http://search.ebscohost.com/login.aspx?dir ect=true \&db=buh\&AN=9386991\&site=ehost-live

European Institute for Gender Equality (2019, February 26). Promoting gender equality in academia and research institutions Main findings. Retrieved from https://eige.europa.eu/publications/ promoting-gender-equality-academia-and-research-institutions-main-findings.

Flores, M. F. (2016). Methods of research in business education. Intramuros, Manila: Unlimited Books Library Services \& Publishing.

Flynn, P. M., Cavanagh, K. V., \& Bilimoria, D. (2019). Gender equality in business schools. In Integrating Gender Equality into Business and Management Education (pp. 26-54). Routledge. https://doi. org/10.4324/9781351285766-3

Frances, C. (2017). Women in American Higher Education: A Descriptive Profile. The Changing Role of Women in Higher Education (pp. 31-52). Springer International Publishing. https://doi. org/10.1007/978-3-319-42436-1_2

Frances, C. (2018). The Status of Women in American Higher Education. Sociology and Anthropology, 6(9), 695-708. https://doi.org/10.13189/sa.2018.060902

Fraser, N. (2013). Fortunes of Feminism. From State-Managed Capitalism to Neoliberal Crisis, 248. Retrieved from http://books.google.com/books?id=PPX-ngEACAAJ\&dq=intitle:Fortunes+of+Feminism \&hl=\&cd=2\&source=gbs_api\%5Cnpapers3://publication/uuid/CE87BA00-FD68-4E38-9D5A0B5BB376A5A7

Goastellec, G., \& Vaira, M. (2017). Women's Place in Academia: Case Studies of Italy and Switzerland. The Changing Role of Women in Higher Education (pp. 173-191). Springer International Publishing. https://doi.org/10.1007/978-3-319-42436-1_9

Goastellec, G., \& Pekari, N. (2013). Gender differences and inequalities in academia: Findings in Europe. In The Work Situation of the Academic Profession in Europe: Findings of a Survey in Twelve Countries (pp. 55-78). Springer Netherlands. https://doi.org/10.1007/978-94-007-5977-0_4

Greene, A. M., \& Kirton, G. (2002). Advancing gender equality: The role of women-only trade union education. Gender, Work, and Organization, 9(1), 39-59. https://doi.org/10.1111/14680432.00148

Grenz, S., Kortendiek, B., Kriszio, M., \& Löther, A. (2008). Gender Equality Programmes in Higher Education - Introduction. In Gender Equality Programmes in Higher Education (pp. 7-12). VS Verlag für Sozialwissenschaften. https://doi.org/10.1007/978-3-531-91218-9_1

Hanaysha, J. (2016). Improving employee productivity through work engagement: Evidence from the higher education sector. Management Science Letters, 61-70. https://doi.org/10.5267/j. msl.2015.11.006 
Henkel, M. (2016). Gender Equality in Academic Career Progression: A Matter of Time? The Changing Role of Women in Higher Education, 195-207. doi: 10.1007/978-3-319-42436-1_10

Hernandez-Nicolas, C. M., Martín-Ugedo, J. F., \& Mínguez-Vera, A. (2015). The influence of gender on financial decisions: Evidence from small start-up firms in Spain. E a M: Ekonomie a Management, 18(4), 93-107. https://doi.org/10.15240/tul/001/2015-4-007

Hill, C. W. L., Jones, G. R., \& Schilling, M. (2016). Strategic management - Theory: An integrated approach. Strategic Management: An Integrated Approach (p. 528). Cengage learning.

Hunt, V., Layton, D., \& Prince, S. (2015). Why diversity matters | McKinsey. Online McKinsey.Com. https:// doi.org/https://business.tutsplus.com/tutorials/advantages-of-promoting-diversity-in-yourbusiness--cms-28259

International Monetary Fund. (2014). International Monetary Fund Annual Report 2014: From stabilization to sustainable growth. Retrieved from https://www.imf.org/en/Publications/AREB/ Issues/2016/12/31/International-Monetary-Fund-Annual-Report-2014-From-stabilization-tosustainable-growth-41823

Kabeer, N. (2012). Women's economic empowerment and inclusive growth: labor markets and enterprise development. Centre for Development Policy and Research. Retrieved from https://www.idrc. ca/sites/default/files/sp/Documents\%20EN/NK-WEE-Concept-Paper.pdf

Kasan, U., Cabanos, P.J.R., Escosura, A.M., Lemus, K.C., \& Mantes, E. (2016). The extent of implementation of gender equality policy at Brady Philippines Corporation: Basis for Continuous Improvement. LPU-Laguna Business and Accountancy Journal, 1(3). Ipulaguna.edu.ph > wpcontent , uploads , 2017/03 > Extent-pf-Impleme.

Kato, T., \& Kodama, N. (2017). Women in the workplace and management practices: Theory and evidence. In The Oxford Handbook of Women and the Economy (pp. 561-594). Oxford University Press. https://doi.org/10.1093/oxfordhb/9780190628963.013.33

Kuiper, E., \& Sap, J. (1996). Out of the Margins: Feminist Perspectives on Economics. Retrieved from https://journals.sagepub.com/doi/abs/10.1177/030981689606000113?journalCode= cnca\#articleCitationDownloadContainer

Lahti, E. (2013). Women and leadership: factors that influence women's career success. Female leaders' reflections on their career development and leadership. Lahti University of Applied Sciences. Retrieved from https://www.theseus.fi/bitstream/handle/10024/66172/Lahti_Elsi.pdf.pdf?seque

Lawshe, C. H. (1975). A Quantitative Approach to Content Validity. Personnel Psychology, 28(4), 563-575. https://doi.org/10.1111/j.1744-6570.1975.tb01393.x

Leal, R. C., \& Saguibo, O. S. (2018). Gender Responsiveness: The Municipality of San Mateo Case. KnE Social Sciences, 3(6), 1090. https://doi.org/10.18502/kss.v3i6.2440

Lualhati, G. P. (2019). Gender Sensitizing: Examining Filipino Educators' Pedagogical Practices and Teaching Effectiveness. Asia Pacific Journal of Multidisciplinary Research, 7(1), 67-76.

Mabokela, R. O., \& Mlambo, Y. A. (2016). Women, Leadership, and Organizational Culture in Higher Education: Lessons Learned from South Africa and Ghana. The Changing Role of Women in Higher Education, 75-92. doi: 10.1007/978-3-319-42436-1_4

Machin, S., \& Wyness, G. (2017). Inequality in Higher Education and the Labor Market. Encyclopedia of International Higher Education Systems and Institutions, 1-9. doi: 10.1007/978-94-017-95531_24-1

Marinova, J. H., Plantenga, J., \& Remery, C. L. H. S. (1970, January 1). Gender Diversity and Firm Performance: Evidence from Dutch and Danish Boardrooms, by J.H. Marinova; J. Plantenga; C.L.H.S. Remery. Retrieved from https://ideas.repec.org/p/use/tkiwps/1003.html

Marr, B. (2012). Key Performance Indicators (KPI): The 75 measures every manager needs to know. Retrieved from books.google.com

McElhaney, K., \& Smith, G. (2017). Eliminating the Pay Gap: An Exploration of Gender Equality ... Retrieved from https://www.icrw.org/wp-content/uploads/2017/11/Eliminating-the-Pay-Gap-KellieMcElhaney-and-Genevieve-Smith.pdf

Monks, K. (2007, January). The Business Impact of Equality and Diversity. https://www.researchgate.net/ publication/253754581_The_Business_Impact_of_Equality_and_Diversity

Moore, S. (1999). Understanding and managing diversity among groups at work: Key issues for organizational training and development. Journal of European Industrial Training, 23, 208218.10.1108/03090599910272086 [Crossref], [Google Scholar] 
Morley, L., Berma, M., \& Abdul Hamid, B. D. (2017). Managing Modern Malaysia: Women in Higher Education Leadership. The Changing Role of Women in Higher Education (pp. 137-154). Springer International Publishing. https://doi.org/10.1007/978-3-319-42436-1_7

Nair, N. V., \& Moolakkattu, J. S. (2018). Gender-Responsive Budgeting: The Case of a Rural Local Body in Kerala. SAGE Open, 8(1). https://doi.org/10.1177/2158244017751572

Noland, M., Moran, T., \& Kotschwa, B. (2016, February). Is Gender Diversity Profitable? Evidence from a Global Survey. Retrieved from https://www.piie.com/publications/wp/wp16-3.pdf

O'Connor, A. S., \& Manaus. (2017, October). Improving business performance through gender equality. Retrieved from http://levistrauss.com/wp-content/uploads/2015/03/IMPROVING-BUSINESSPERFORMANCE-THROUGH-GENDER-EQUALITY_OCT-2017_FINAL.pdf

OECD. (2017). The Pursuit of Gender Equality: An Uphill Battle. Report (p. 306). https://doi. org/10.1787/9789264281318-en

Out of the Margins: Feminist Perspectives on Economics. (1996). Capital \& Class, 20(3), 147-149. https:// doi.org/10.1177/030981689606000113

Papadimitriou, A. (2017). Female Academics in Greek Higher Education: Issues of Organizational Change, Economic Crisis, and Social Responsibility. In The Changing Role of Women in Higher Education (pp. 119-136). Springer International Publishing. https://doi.org/10.1007/978-3-319-42436-1_6

Parida, A. (2007). Study and analysis of maintenance performance indicators (MPIs) for LKAB: A case study. Journal of Quality in Maintenance Engineering, 13(4), 325-337. https://doi. org/10.1108/13552510710829434

Peterson, H. (2011). The gender mix policy - addressing gender inequality in higher education management. Retrieved from https://www.tandfonline.com/doi/abs/10.1080/1360080X.2011.621188

Profeta, P. (2017). Gender Equality in Decision-Making Positions: The Efficiency Gains. Intereconomics, 52(1), 34-37. https://doi.org/10.1007/s10272-017-0640-4

Remme, M., Siapka, M., Vassall, A., Heise, L., Jacobi, J., Ahumada, C., \& Watts, C. (2014, November 4). The cost and cost-effectiveness of gender-responsive interventions for HIV: A systematic review. Journal of the International AIDS Society. International AIDS Society. https://doi.org/10.7448/ IAS.17.1.19228

Republic Act No. 7192: GOVPH. (1992, February 12). Retrieved from https://www.officialgazette.gov. ph/1992/02/12/republic-act-no-7192/

Republic Act No. 9710: GOVPH. (2009, August 14). Retrieved from https://www.officialgazette.gov. $\mathrm{ph} / 2009 / 08 / 14 /$ republic-act-no-9710

Robertson, J., Williams, A., Jones, D., Isbel, L., Loads, D., \& Maxwell, E. (2018). EqualBITE: gender equality in higher education. Rotterdam: Sense Publishers.

Roja, L. O., \& Pérez Orozco, A. (2014). Del trabajo doméstico al trabajo de cuidados. Retrieved from https:// issuu.com/laovejaroja/docs/amaia

Santiago, C. (2008, July). Philippines: Country Gender Profile. Retrieved from https://www.jica.go.jp/english/ our_work/thematic_issues/gender/background/pdf/e08phi.pdf

Schneider, T., Akinbosede, D., \& Macfarlane, B. (2015, May 26). Cycle of domination of top roles by men must be broken. Retrieved from https://www.timeshighereducation.com/news/cycle-ofdomination-of-top-roles-by-men-must-be-broken/422031.article

Sharma, M. S., \& Sharma, M. V. (2014). Employee Engagement to Enhance Productivity in Current Scenario. International Journal of Commerce, Business, and Management (IJCBM), 3(4), 10.

Shauka, S., Siddiquah, A., \& Pell, W.A (2014). Gender discrimination in higher education in Pakistan: A survey of university faculty. Eurasian Journal of Educational Research, 56, 109-126 http://dx.doi. org/10.14689/ejer.2014.56.2

Shreve, C. (2016). Economic efficiency on gender equality: conceptualizing an equitable "social framing for economic evaluation to support gender equality in disaster-risk and environmental management decision-making. MDPI. doi: 10.3390/resources5030025

Silva, M. (2002). Ways to Gender Responsive Organization. Tools and Guides for Gender Responsiveness in Government Organizations. National Commission on the Role of Women and the Canadian International Development Agency.

Stamarski, C. S., \& Son Hing, L. S. (2015). Gender inequalities in the workplace: the effects of organizational structures, processes, practices, and decision-makers' sexism. Frontiers in Psychology, 6. https:// doi.org/10.3389/fpsyg.2015.01400 
Sumadsad, C., \& Tuazon, A. (2016, September 14). Gender and Development (GAD) Awareness in a Higher Education Institution. Retrieved from https://papers.ssrn.com/sol3/papers.cfm?abstract_ id $=2838156$

Williams, W., Christopher F., C., Alexander, P., Nada, H., \& Thomas W., M. (2010). Evidence for a Collective Intelligence Factor in the Performance of Human Groups. SCIENCE, 330(29 October), 686.

World Atlas of Gender Equality in Education (2012). Retrieved from https://www.macfound.org/media/files/ UNESCO-world-atlas-gender-education.pdf

Women's Empowerment Principles: Equality Means Business. (2011). Retrieved from https://www. unwomen.org/en/digital-library/publications/2011/10/women-s-empowerment-principlesequality-means-business

Wodon, Q. T., \& De La Briere, B. (2018). Unrealized Potential: The High Cost of Gender Inequality in Earnings. In The Cost of Gender Inequality (pp. 1-28). The World Bank. Retrieved from http://documents. worldbank.org/curated/en/172021527258723053/Unrealized-potential-the-high-cost-of-genderinequality-in-earnings

Zhao, J., \& Jones, K. (2017). Women and Leadership in Higher Education in China: Discourse and the Discursive Construction of Identity. Administrative Sciences, 7(3), 21. https://doi.org/10.3390/ admsci7030021

Zhong, Z., \& Guo, F. (2017). Women in Chinese Higher Education: Educational Opportunities and Employability Challenges. In The Changing Role of Women in Higher Education (pp. 53-73). Springer International Publishing. https://doi.org/10.1007/978-3-319-42436-1_3

Zuabi, R. (2015). The bottom line- Why Gender Inclusion is Good for Business. Retrieved from http://www. v4w.org/images/generales/Resources/BottomLine_2015_08.pdf 